\title{
Assessment of radiation hazard indices for sand samples from Ma'rib in Yemen
}

\author{
M.M.M. Ali1,2, H. Zhao",3* ${ }^{\text {, }}$ A. Rawashdeh1, Y.A. Mohammed4, \\ M. Al Hassan4 \\ ${ }^{1}$ Collage of Nuclear Science and Technology, Harbin Engineering University, Harbin 150001, China \\ ${ }^{2}$ National Atomic Energy Commission-Yemen (NATEC), Sana'a, Yemen \\ ${ }^{3}$ College of Physics and Optoelectronic Engineering, Harbin Engineering University, Harbin 150001, China \\ ${ }^{4}$ College of Materials Science and Chemical Engineering, Harbin Engineering University, Harbin, China, 150001
}

\begin{abstract}
- Original article

*Corresponding authors:
Hongtao Zhao,Ph.D.,
E-mail:
mohsenzmra7777@gmail.com
Revised: June 2020
Accepted: July 2020
Int. J. Radiat. Res., July 2021;
19(3): 615-623
DOI: 10.29252/ijrr.19.2.615

Background: This study aimed to investigate the radiation hazard indices from sand samples of Ma'rib Governorate in Yemen, where the majority of oil and gas facilities are installed. Methods and Materials: Thirty five samples of desert sand from Ma'rib Governorate in Yemen were collected and tested their radiation hazard indices by using High Purity Germanium (HPGe) detector. Results: Based on the measurement of the concentrations of ${ }^{226} \mathrm{Ra},{ }^{232} \mathrm{Th}$, and ${ }^{40} \mathrm{~K}$, the radium equivalent activity $\left(\mathrm{Ra}_{\text {eq }}\right)$, the activity concentration index $\left(\mathrm{I}_{\psi}\right)$, the external hazard index $\left(\mathrm{H}_{\mathrm{ex}}\right)$ and the internal hazard index $\left(\mathrm{H}_{\text {in }}\right)$ were all calculated. Also, the absorbed dose rate in Air (ADR) and the annual effective dose (AED) are calculated. Conclusions: Comparing the practically attained results with internationally permissible values, it was found that most of the radiological parameters, including the radiation hazard indices of the studied samples, fall within the world's permissible limits and don't expose risks to the human beings and environments.
\end{abstract}

Keywords: Natural radioactivity, sand samples, HPGe detector, annual effective dose.

\section{INTRODUCTION}

Naturally occurring radioactive materials (NORMs) are found in rocks, soil, sand, and water since the formation of the Earth. Some of these radioactive materials have very long half-lives for dissolution (hundreds of millions years or more). A large quantity of these nuclides is still present on the Earth until now. Human's and technological activities may lead to enhancement of these materials to higher levels, in such case, these are called technologically enhanced naturally occurring radioactive materials (TENORM) (1-4).

One of the most important types of environmental pollution is radioactive pollution, which is the spread of radioactive materials in topsoil, sand, rocks, and water, whether this spread is natural or as a result of anthropogenic activities.. Therefore, a lot of studies and surveys of air, soil, sand, rocks, water, food, and others have been conducted to measure the level of radiation doses to which inhabitants of this planet are exposed continually (5-9).

The International Atomic Energy Agency (IAEA) and the US Environmental Protection Agency (EPA) have published guidelines for tracking exposure to natural radiation for human health. Soils, sand, and sediments are amongst some sources of human exposure to natural radiation. Radiation sources may also transmit to our food and biological chain from the soil, causing extra health risks. The food chain is one of the major pathways for the 
migration of radioactive pollutants. Humans are mainly exposed to natural radiation that originates mostly from above $30 \mathrm{~cm}$ above the Earth's surface. Since these radionuclides are not uniformly distributed, knowledge of their distribution in soil, sand, and rocks plays an important role in radiation dose measurement and protection (10-12).

The petroleum industry and the residues of its derivatives are all considered as radioactive pollutants to human health. The groundwater wells contain large quantities of formation water along with crude oil. This water contains naturally radioactive materials that are transported to the Earth's surface during the extraction process. These materials pose a great danger to the environment in the areas of production, refining, and distribution, as well as across various transmission lines $(3,4)$.

Upon contamination with such radioactive materials, the air, soil, and water environments are adversely affected. Accordingly, the responsible of petroleum industries are concerned with managing this issue by recycling the oil wastes through costly processes and via high technologies. Therefore, studying the radiological hazards resulting from oil industries has magnetised great attention of researchers nowadays all over the world to reduce the remains of such environmental risks. However, more investigations regarding these hazards and its negative impacts are still required $(3,4,13)$.

The desert region of Ma'rib in Yemen is a potential area for radioactive consequences. Therefore it is desirable to conduct a study in this region. This is the first time that such a study has been conducted. In light of this, the current study aims to asses the indicators of radiological hazards, generated by oil and gas industries, for sand samples in Ma'rib desert in Yemen. This article mainly addresses the parameters including radium equivalent activity $\left(\mathrm{Ra}_{\mathrm{eq}}\right)$ activity concentration index $(I \gamma)$, external hazard index $\left(\mathrm{H}_{\mathrm{ex}}\right)$, internal hazard index $\left(\mathrm{H}_{\mathrm{in}}\right)$, absorbed dose rate in the air (ADR) and annual effective dose (AED) of the radioactivity concentration of the ${ }^{238} \mathrm{U}$, ${ }^{232} \mathrm{Th}$, and ${ }^{40} \mathrm{~K}$ in sand samples obtained from different locations in Ma'rib. Moreover, this study can be used to set a reference line for further work in the future, focusing on the radioactivity level in this territory.

\section{MATERIALS AND METHODS}

\section{Geology of study area}

Governorate of Ma'rib in the central of Yemen, which is located in the northeastern part of Sana'a, the capital of Yemen. located between latitude $\left(15^{\circ}\right.$ $\left.23^{\prime} 40.73^{\prime \prime}, 16^{\circ} 7^{\prime} 29.55^{\prime \prime} \mathrm{N}\right)$ and longitude (45 10'32.28", $44^{\circ} 46^{\prime} 33.83^{\prime \prime E)}$ at an altitude of 944 meters above sea level. Google Earth and GPS were used to record the exact coordinates of the collected samples from the study area, as shown in figure 1 and table 1. This desert area has less rainfall throughout the year, due to which the agriculture of this area is greatly affected. The Governorate of Ma'rib is the first of the Yemeni governorates where most of the production and processing facilities of oil and gas are installed since $1986(14,15)$.

\section{Sample collection and processing}

Thirty-five sand samples were collected from various sites of Ma'rib desert centre, and its borders and their geological coordinates are given in figure 1 and table 1 . The collected sand samples are categorised as "SO" and "SN". All samples in category "SO" were collected from inside and nearby surroundings of the oil and gas facilities, where a total of twinty one samples were collected. All other samples in category "SN" were taken from sites that have no history of oil exploitation and production but with similar geographic and geological characteristics to oil and gas societies, where a total of twinty one samples were collected. The samples collected in a manner consistent with the achievement of the study objectives. Each sand sample was taken directly from natural exposures from surface pits at a depth of $20-50 \mathrm{~cm}$ from the outer surface. All organic materials larger than $1 \mathrm{~mm}$ in size were excluded from the collected samples. These samples were subsequently transported to the laboratory for further process and analysis.

In the laboratory, the samples were dried, ground, and sieved. All prepared samples were kept in unused plastic containers.

Radioisotopes for sand samples were determined by taking a volume of $65 \mathrm{~mL}$ from each sample. The samples were kept in tightly closed containers (Petri Dish). The Petri dishes

Int. J. Radiat. Res., Vol. 19 No. 3, July 2021 
were sealed tightly to avoid any leakage of radon. Prior to measurements, samples were preserved at same conditions by leaving in the laboratory for one month to ensure the secular equilibrium of radium isotopes and their short-lived decay products.

Table 1. Location coordinates values.

\begin{tabular}{|c|c|c|c|}
\hline \multirow{2}{*}{ Simple } & \multirow{2}{*}{ Region Name } & \multicolumn{2}{|c|}{ Position } \\
\hline & & Longitude $\left({ }^{\circ} \mathrm{E}\right)$ & Latitude $\left({ }^{\circ} \mathrm{N}\right)$ \\
\hline $\mathrm{SO}_{1}$ & Almazarie & $45^{\circ} 47^{\prime} 23.74^{\prime \prime}$ & $15^{\circ} 33^{\prime} 32.45^{\prime \prime}$ \\
\hline $\mathrm{SO}_{2}$ & Kara & $45^{\circ} 48^{\prime} 58.56^{\prime \prime}$ & $15^{\circ} 31^{\prime} 36.46^{\prime \prime}$ \\
\hline $\mathrm{SO}_{3}$ & Al jamil & $45^{\circ} 46^{\prime} 2.25^{\prime \prime}$ & $15^{\circ} 32^{\prime} 22.40^{\prime \prime}$ \\
\hline $\mathrm{SO}_{4}$ & Aljathua & $45^{\circ} 41^{\prime} 13.47^{\prime \prime}$ & $15^{\circ} 32^{\prime} 45.41^{\prime \prime}$ \\
\hline $\mathrm{SO}_{5}$ & Alhani & $45^{\circ} 44^{\prime} 45.85^{\prime \prime}$ & $15^{\circ} 35^{\prime} 42.01^{\prime \prime}$ \\
\hline $\mathrm{SO}_{6}$ & Alhazma & $45^{\circ} 33^{\prime} 3.41^{\prime \prime}$ & $15^{\circ} 33^{\prime} 31.91^{\prime \prime}$ \\
\hline $\mathrm{SO}_{7}$ & Alrubue & $45^{\circ} 49^{\prime} 19.14^{\prime \prime}$ & $15^{\circ} 35^{\prime} 41.79^{\prime \prime}$ \\
\hline $\mathrm{SO}_{8}$ & Alramsa & $45^{\circ} 43^{\prime} 57.47^{\prime \prime}$ & $15^{\circ} 30^{\prime} 8.68^{\prime \prime}$ \\
\hline $\mathrm{SO}_{9}$ & Alearaqa & $45^{\circ} 35^{\prime} 27.57^{\prime \prime}$ & $15^{\circ} 30^{\prime} 28.25^{\prime \prime}$ \\
\hline $\mathrm{SO}_{10}$ & Alghawia & $45^{\circ} 30^{\prime} 31.14^{\prime \prime}$ & $15^{\circ} 30^{\prime} 46.97^{\prime \prime}$ \\
\hline $\mathrm{SO}_{11}$ & Alghajla & $45^{\circ} 39^{\prime} 8.27^{\prime \prime}$ & $15^{\circ} 27^{\prime} 18.24^{\prime \prime}$ \\
\hline $\mathrm{SO}_{12}$ & Sulua & $45^{\circ} 45^{\prime} 16.15^{\prime \prime}$ & $15^{\circ} 27^{\prime} 10.47^{\prime \prime}$ \\
\hline $\mathrm{SO}_{13}$ & Almumlah & $45^{\circ} 56^{\prime} 27.38^{\prime \prime}$ & $15^{\circ} 37^{\prime} 14.14^{\prime \prime}$ \\
\hline $\mathrm{SO}_{14}$ & Al shabwan & $46^{\circ} 0^{\prime} 15.73^{\prime \prime}$ & $15^{\circ} 39^{\prime} 41.10^{\prime \prime}$ \\
\hline $\mathrm{SO}_{15}$ & Althaman & $45^{\circ} 59^{\prime} 8.61^{\prime \prime}$ & $15^{\circ} 36^{\prime} 45.72^{\prime \prime}$ \\
\hline $\mathrm{SO}_{16}$ & Alkhushea & $46^{\circ} 1^{\prime} 55.71^{\prime \prime}$ & $15^{\circ} 37^{\prime} 21.73^{\prime \prime}$ \\
\hline $\mathrm{SO}_{17}$ & Alshaykh & $45^{\circ} 58^{\prime} 46.52^{\prime \prime}$ & $15^{\circ} 33^{\prime} 17.33^{\prime \prime}$ \\
\hline $\mathrm{SO}_{18}$ & Alshamar & $45^{\circ} 58^{\prime} 1.37^{\prime \prime}$ & $15^{\circ} 36^{\prime} 20.28^{\prime \prime}$ \\
\hline $\mathrm{SO}_{19}$ & Aljudean & $45^{\circ} 52^{\prime} 26.39^{\prime \prime}$ & $15^{\circ} 35^{\prime} 2.77^{\prime \prime}$ \\
\hline $\mathrm{SO}_{20}$ & Alrashid & $45^{\circ} 50^{\prime} 11.39 "$ & $15^{\circ} 40^{\prime} 11.06^{\prime \prime}$ \\
\hline $\mathrm{SO}_{21}$ & Al misheal & $45^{\circ} 57^{\prime} 28.71^{\prime \prime}$ & $15^{\circ} 27^{\prime} 2.41^{\prime \prime}$ \\
\hline $\mathrm{SN}_{1}$ & Jawalnasim & $46^{\circ} 32^{\prime} 39.29^{\prime \prime}$ & $16^{\circ} 0 ' 26.08^{\prime \prime}$ \\
\hline $\mathrm{SN}_{2}$ & Alhusuwn & $46^{\circ} 18^{\prime} 35.01^{\prime \prime}$ & $15^{\circ} 58^{\prime} 1.31^{\prime \prime}$ \\
\hline $\mathrm{SN}_{3}$ & Alghajla & $46^{\circ} 25^{\prime} 1.88^{\prime \prime}$ & $15^{\circ} 50^{\prime} 32.40^{\prime \prime}$ \\
\hline $\mathrm{SN}_{4}$ & Al jalal & $46^{\circ} 4^{\prime} 38.83^{\prime \prime}$ & $15^{\circ} 52^{\prime} 56.42^{\prime \prime}$ \\
\hline $\mathrm{SN}_{5}$ & Al fajayh & $46^{\circ} 13^{\prime} 6.36^{\prime \prime}$ & $15^{\circ} 43^{\prime} 28.38^{\prime \prime}$ \\
\hline $\mathrm{SN}_{6}$ & Al jabir & $45^{\circ} 40^{\prime} 52.39^{\prime \prime}$ & $15^{\circ} 44^{\prime} 51.41^{\prime \prime}$ \\
\hline $\mathrm{SN}_{7}$ & Alhuma & $45^{\circ} 27^{\prime} 2.06^{\prime \prime}$ & $15^{\circ} 37^{\prime} 46.31^{\prime \prime}$ \\
\hline $\mathrm{SN}_{8}$ & Fyfil & $45^{\circ} 31^{\prime} 55.25^{\prime \prime}$ & $15^{\circ} 23^{\prime} 18.87^{\prime \prime}$ \\
\hline $\mathrm{SN}_{9}$ & Al misheal & $45^{\circ} 40^{\prime} 54.69^{\prime \prime}$ & $15^{\circ} 21^{\prime} 48.72^{\prime \prime}$ \\
\hline $\mathrm{SN}_{10}$ & Althania & $45^{\circ} 33^{\prime} 51.04^{\prime \prime}$ & $15^{\circ} 16^{\prime} 16.37^{\prime \prime}$ \\
\hline $\mathrm{SN}_{11}$ & Al qazea & $45^{\circ} 43^{\prime} 51.18^{\prime \prime}$ & $15^{\circ} 15^{\prime} 4.23^{\prime \prime}$ \\
\hline $\mathrm{SN}_{12}$ & Alhaway & $45^{\circ} 52^{\prime} 38.20^{\prime \prime}$ & $15^{\circ} 22^{\prime} 53.78^{\prime \prime}$ \\
\hline $\mathrm{SN}_{13}$ & Altahil & $45^{\circ} 53^{\prime} 29.61^{\prime \prime}$ & $15^{\circ} 45^{\prime} 7.70^{\prime \prime}$ \\
\hline $\mathrm{SN}_{14}$ & Al munif & $46^{\circ} 14^{\prime} 14.33^{\prime \prime}$ & $15^{\circ} 37^{\prime} 38.31^{\prime \prime}$ \\
\hline
\end{tabular}

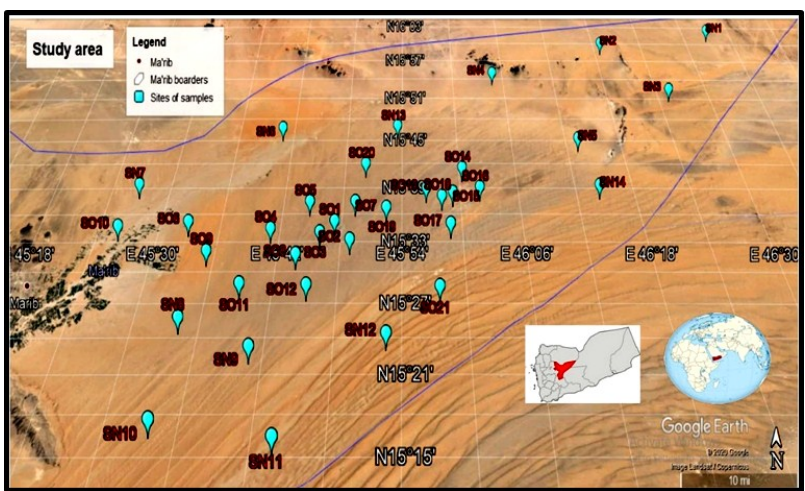

Figure 1. Sample sites are shown on google earth map, and detailed coordinates are recorded in table 1.

\section{Analysis of radiation hazard indices}

Each sample was then measured at a record time of 64,800 seconds using Gamma-ray spectroscopy system of Canberra N-type equipped with a high purity germanium detector (HPGe). The background radiation spectrum was used to determine the minimum detectable activity. The detector has a relative efficiency of $35 \%$ and a resolution of 1.85 .

$\mathrm{KeV}$ for $1332 \mathrm{KeV}$ gamma energy of ${ }^{60} \mathrm{Co}$. The detector is surrounded by a lead shield of $10 \mathrm{~cm}$ thickness to reduce the background radiation levels of the system, as well as, lined from the inside with copper plates of $1 \mathrm{~mm}$ thickness to minimise the $\mathrm{X}$-ray emitted by

Table 2. The gamma-ray and its radioisotopes used to calculate the radioactivity concentrations of TENORM in sand samples.

\begin{tabular}{|c|c|c|}
\hline Nuclide & Gamma-ray energy (KeV) & Radioisotope \\
\hline \multirow{2}{*}{${ }^{226} \mathrm{Ra}$} & $609.32,1120.28$ and 1764.91 & ${ }^{214} \mathrm{Bi}$ \\
\cline { 2 - 3 } & 295.21 and 351.93 & ${ }^{214} \mathrm{~Pb}$ \\
\hline${ }^{232} \mathrm{Th}$ & $338.40,911.20$ & ${ }^{228} \mathrm{Ac}$ \\
\hline${ }^{40} \mathrm{~K}$ & 1460.83 & ${ }^{40} \mathrm{~K}$ \\
\hline
\end{tabular}

Where, A is the radioactivity concentrations, $\mathrm{N}_{\text {net }}$ is the net area under photo-peak, $\varepsilon$ is the efficiency of the detector, I $\gamma$ is the transition probability of the emitted gamma-ray (Effectiveness concentration factor), $\mathrm{m}$ is the sample weight in kilograms, $t$ is the time for the collected spectrum (in seconds). Depending on the activity concentrations of the radioactive nuclides of ${ }^{226} \mathrm{Ra},{ }^{232} \mathrm{Th}$, and ${ }^{40} \mathrm{~K}$, various radiation hazard indices are calculated as follows: 


\section{Radium Equivalent Activity ( $\left.R a_{e q}\right)$}

The value of the equivalent activity of radium $\left(R a_{\text {eq }}\right)$, which is used to estimate the risk of the concentration due to the effectiveness of $226 \mathrm{Ra}$, ${ }^{232} \mathrm{Th}$, and ${ }^{40} \mathrm{~K}$ in units of Bq. $\mathrm{kg}^{-1}$ is evaluated according to equation 2 (19-23).

$$
\mathrm{Ra}_{\mathrm{eq}}\left(\mathrm{Bq} \cdot \mathrm{kq}^{-1}\right)=\mathrm{A}_{\mathrm{Ra}}+1.43 \times \mathrm{A}_{\mathrm{Th}}+0.077 \mathrm{~A}_{\mathrm{K}}
$$

Where, $A_{\text {Ra }}, A_{\text {Th, }}$ and $A_{K}$ are represent the radioactivity concentrations of radium, thorium, and potassium, respectively, and the highest value of $\left(\mathrm{Ra}_{\mathrm{eq}}\right)$ must be less than the global tolerance limit of $\left(370 \mathrm{~Bq} \cdot \mathrm{kq}^{-1}\right)^{(17)}$.

\section{Activity Concentration Index (I $\gamma$ )}

The activity concentration index is a coefficient used to calculate the risk arising from the radiation of gamma coupled with nuclides ${ }^{226} \mathrm{Ra}$, ${ }^{232} \mathrm{Th}$, and ${ }^{40} \mathrm{~K}$ ) in the studied samples and is estimated by by equation $3(20,21,24)$.

$\mathrm{I}_{\gamma}=\frac{A_{R a}}{150}+\frac{A_{T h}}{100}+\frac{A_{K}}{1500}$

\section{External Hazard Index $\left(\mathrm{H}_{e x}\right)$}

External hazards represent the ionised hazards of the natural external gamma radiation. The aim is to ensure that the effective dose of this radiation does not exceed the permissible limits. The hazard coefficient is calculated evaluated using equation $4(20,22,24)$.

$\mathrm{H}_{e x}=\frac{A_{R a}}{370}+\frac{A_{T h}}{259}+\frac{A_{K}}{4810}$

\section{Internal Hazard Index $\left(\mathrm{H}_{\text {in }}\right)$}

Inhaling alpha particles emitted from short-lived isotopes such as radon and thoron, that are accompanied by gamma-rays having different energies, which can be expressed by the internal hazard index as per the equation $5(20,22$, 24).

$$
\mathrm{H}_{\text {in }}=\frac{A_{R a}}{185}+\frac{A_{T h}}{259}+\frac{A_{K}}{4810}
$$

The amount of internal risks is preferable to be less than one in the ideal environment to ensure workplace safety of the respiratory organs and for the survival of individuals.

\section{Absorbed Dose Rate in Air (ADR)}

The total percentage of the absorbed dose rate in the air can be calculated in terms of the concentrations of terrestrial nuclei by equation 6 (20-24).

$$
\operatorname{ADR}\left(\text { nGy.h }{ }^{-1}\right)=0.462 \mathrm{~A}_{\mathrm{Ra}}+0.621 \times \mathrm{A}_{\mathrm{Th}}+0.0417 \times \mathrm{A}_{\mathrm{K}}
$$

\section{Annual Effective Dose (AED)}

In order to calculate the annual effective dose, (the conversion factor from the absorbed 105 dose, and the internal occupancy factor) must be considered. UNSCEAR 2000 has published the 0.7 Sv/Gy as a conversion factor from the dose absorbed of the gamma-ray emitter in the air to the annual effective dose received by adults. Assuming 0.20 is the ratio of time spent outdoors, where the number of hours in a year are considered to be 8760 . accordingly, the annual effective dose can be evaluated by equations7 (11, $20,23,24)$.

$A E D\left(\mu S v \cdot y^{-1}\right)=A D\left(\frac{n C y}{h}\right) \times 10^{-6} \times 8760 \frac{h}{y} \times 0.20 \times 0.7 \frac{S v}{G y}$

The annual effective dose (AED) of outdoor gamma radiation is preferably less than the global average of $460 \mu \mathrm{Sv}^{-y^{-1}}$. Radiation hazard indices were calculated and the results are are summarised in tables 3 and 4 .

\section{Statistical analysis}

The IBM SPSS-25 computer program was used to perform all the statistical assessments. Due to the non-parametric data set, the iterative distribution of the data was tested against the normal or logarithmic normal distribution by the Kolmogorov-Smirnov test (K-S) at the significance level ( $p>0.05$ ).

Statistical significance differences were calculated between samples taken from oil and non-oil societies using Mann-Whitney test (M-W) at the significance level $(\mathrm{p}<0.05)$. The average, variance, standard deviation, minimum, maximum, skewness (degree of symmetry degradation) and kurtosis factor (peak degree) parameters were counted. The statistical data are summarised in tables 3, 4 and 5.

Int. J. Radiat. Res., Vol. 19 No. 3, July 2021 
Table 3. Radiation hazard indices for sand samples collected from Ma'rib region of Yemen (category "SO").

\begin{tabular}{|c|c|c|c|c|c|c|}
\hline Simple & \begin{tabular}{|c|}
$\mathrm{Ra}_{\mathrm{eq}}$ \\
$\mathrm{Bq} \cdot \mathrm{Kg}^{-1}$
\end{tabular} & Ip & Hex & $\mathrm{H}_{\text {in }}$ & $\begin{array}{c}\text { ADR } \\
\text { nGy.h } h^{-1}\end{array}$ & $\begin{array}{c}\text { AED } \\
\left(\mu S v \cdot y^{-1}\right)\end{array}$ \\
\hline $\mathrm{SO}_{1}$ & 116.376 & 0.914 & 0.325 & 0.356 & 57.500 & 70.518 \\
\hline $\mathrm{SO}_{2}$ & 95.337 & 0.756 & 0.264 & 0.303 & 47.846 & 58.679 \\
\hline $\mathrm{SO}_{3}$ & 71.638 & 0.572 & 0.195 & 0.245 & 36.565 & 44.843 \\
\hline $\mathrm{SO}_{4}$ & 105.186 & 0.807 & 0.292 & 0.366 & 51.566 & 63.241 \\
\hline $\mathrm{SO}_{5}$ & 97.842 & 0.765 & 0.272 & 0.318 & 48.457 & 59.428 \\
\hline $\mathrm{SO}_{6}$ & 76.945 & 0.623 & 0.210 & 0.249 & 39.577 & 48.537 \\
\hline $\mathrm{SO}_{7}$ & 112.536 & 0.873 & 0.311 & 0.383 & 55.671 & 68.275 \\
\hline $\mathrm{SO}_{8}$ & 83.907 & 0.657 & 0.229 & 0.304 & 42.313 & 51.893 \\
\hline $\mathrm{SO}_{9}$ & 104.966 & 0.817 & 0.293 & 0.333 & 51.605 & 63.289 \\
\hline $\mathrm{SO}_{10}$ & 68.275 & 0.544 & 0.190 & 0.206 & 34.223 & 41.971 \\
\hline $\mathrm{SO}_{11}$ & 85.746 & 0.681 & 0.237 & 0.270 & 43.080 & 52.833 \\
\hline $\mathrm{SO}_{12}$ & 71.830 & 0.581 & 0.196 & 0.231 & 36.873 & 45.221 \\
\hline $\mathrm{SO}_{13}$ & 55.837 & 0.467 & 0.152 & \begin{tabular}{|l|}
0.165 \\
\end{tabular} & 29.400 & 36.057 \\
\hline $\mathrm{SO}_{14}$ & 68.270 & 0.555 & 0.187 & 0.215 & 35.166 & 43.128 \\
\hline $\mathrm{SO}_{15}$ & 108.741 & 0.853 & 0.303 & 0.340 & 53.765 & 65.937 \\
\hline $\mathrm{SO}_{16}$ & 72.082 & 0.580 & 0.197 & 0.238 & 36.910 & 45.266 \\
\hline $\mathrm{SO}_{17}$ & 106.282 & 0.836 & 0.295 & 0.335 & 52.792 & 64.744 \\
\hline $\mathrm{SO}_{18}$ & 96.664 & 0.761 & 0.268 & 0.312 & 48.241 & 59.163 \\
\hline $\mathrm{SO}_{19}$ & 106.548 & 0.834 & 0.294 & 0.355 & 53.031 & 65.037 \\
\hline $\mathrm{SO}_{20}$ & 101.588 & 0.793 & 0.281 & 0.339 & 50.407 & 61.819 \\
\hline $\mathrm{SO}_{21}$ & 99.572 & 0.774 & 0.276 & 0.334 & 49.247 & 60.396 \\
\hline Min & 55.837 & 0.467 & 0.152 & 0.165 & 29.400 & 36.057 \\
\hline Max & 116.376 & 0.914 & 0.325 & 0.383 & 57.500 & 70.518 \\
\hline Ave. & 90.770 & 0.716 & 0.251 & 0.295 & 45.440 & 55.727 \\
\hline 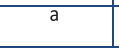 & 370 & $1 \leq$ & $1 \leq$ & $1 \leq$ & 55 & 460 \\
\hline
\end{tabular}

Table 4. Radiation hazard indices for sand samples collected from the Ma'rib region of Yemen (category " SN")

\begin{tabular}{|c|c|c|c|c|c|c|}
\hline Simple & $\begin{array}{c}\mathrm{Ra}_{\mathrm{eq}} \\
\mathrm{Bq} \cdot \mathrm{Kg}^{-1}\end{array}$ & Ip & Hex & $H_{\text {in }}$ & $\begin{array}{c}\text { ADR } \\
n G y \cdot h^{-1}\end{array}$ & $\begin{array}{c}\text { AED } \\
\left(\mu S v \cdot y^{-1}\right)\end{array}$ \\
\hline $\mathrm{SN}_{1}$ & 90.487 & 0.719 & 0.250 & 0.287 & 45.506 & 55.809 \\
\hline $\mathrm{SN}_{2}$ & 84.483 & 0.673 & 0.235 & 0.255 & 42.333 & 51.917 \\
\hline $\mathrm{SN}_{3}$ & 87.969 & 0.699 & 0.244 & 0.275 & 44.130 & 54.121 \\
\hline $\mathrm{SN}_{4}$ & 72.969 & 0.579 & 0.202 & 0.231 & 36.642 & 44.938 \\
\hline $\mathrm{SN}_{5}$ & 74.232 & 0.585 & 0.204 & 0.252 & 37.317 & 45.765 \\
\hline $\mathrm{SN}_{6}$ & 70.679 & 0.570 & 0.193 & 0.230 & 36.262 & 44.471 \\
\hline $\mathrm{SN}_{7}$ & 67.671 & 0.546 & 0.185 & 0.220 & 34.698 & 42.554 \\
\hline $\mathrm{SN}_{8}$ & 72.404 & 0.580 & 0.198 & 0.240 & 36.974 & 45.345 \\
\hline $\mathrm{SN}_{9}$ & 74.840 & 0.603 & 0.206 & 0.230 & 38.019 & 46.627 \\
\hline $\mathrm{SN}_{10}$ & 60.421 & 0.489 & 0.166 & 0.185 & 30.819 & 37.797 \\
\hline $\mathrm{SN}_{11}$ & 88.400 & 0.699 & 0.244 & 0.288 & 44.358 & 54.401 \\
\hline $\mathrm{SN}_{12}$ & 103.968 & 0.824 & 0.289 & 0.318 & 51.834 & 63.570 \\
\hline $\mathrm{SN}_{13}$ & 74.008 & 0.594 & 0.203 & 0.238 & 37.704 & 46.240 \\
\hline $\mathrm{SN}_{14}$ & 61.244 & 0.510 & 0.167 & 0.180 & 32.107 & 39.376 \\
\hline Min & 60.421 & 0.489 & 0.166 & 0.180 & 30.819 & 37.797 \\
\hline Max & 103.968 & 0.824 & 0.289 & 0.318 & 51.834 & 63.570 \\
\hline Ave. & 77.413 & 0.619 & 0.213 & 0.245 & 39.193 & 48.066 \\
\hline $\mathrm{a}$ & 370 & $1 \leq$ & $1 \leq$ & $1 \leq$ & 55 & 460 \\
\hline
\end{tabular}

Int. J. Radiat. Res., Vol. 19 No. 3, July 2021

\section{Radiographic maps}

Radiographic maps were made graphically using the applications Google Earth, TCX 2.5 Converter, Server 9, and Excel software systems. The coordinates of the collected samples were read from GPS. The digital height model for the study area was created by digitising contour lines from standard topographic maps. Radiological maps were made for the most important radiological hazards indicators $\mathrm{Ra}_{\mathrm{eq}}$ and $\mathrm{H}_{\mathrm{in}}$ as in figures 2 and 3.

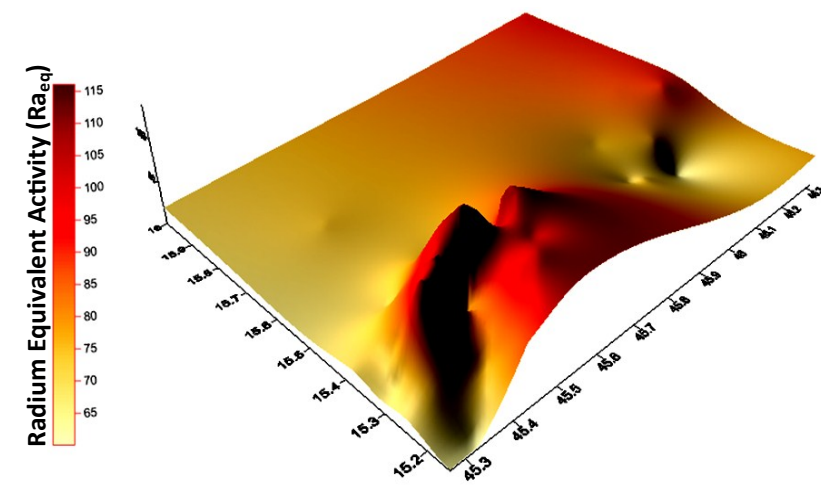

Figure 2. Distribution map of radium equivalent activity $\left(R a_{\text {eq }}\right)$.

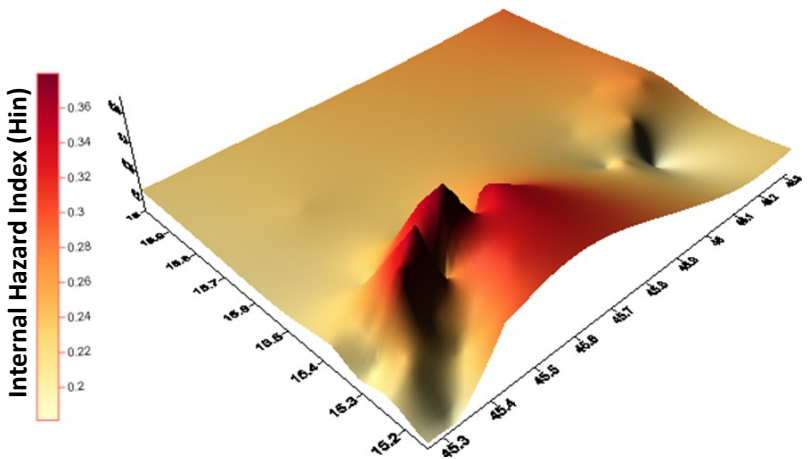

Figure 3. Distribution map of internal hazard index $\left(\mathrm{H}_{\text {in }}\right)$.

\section{RESULTS}

Tables 3 and 4 summarise the results of the radiation hazard indices for this research work. The obtained findings are used to construct contour maps, illustrating the variation in the concentration values of the radiation hazard indices and portraying how these hazards are distributed over the studied areas as shown in figures 2 and 3 . Furthermore, the results are compared with the permissible global averages. 
For oily samples (SO), Raeq ranged from 55.84 to 116.38 Bq.kg- ${ }^{-1}$, with an average of 85.43 Bq.kg-1. $\mathrm{I}_{\gamma}, \mathrm{H}_{\mathrm{ex}}$ and $\mathrm{H}_{\text {in }}$ ranged between 0.47-0.91, 0.15-0.33 and 0.17-0.38 respectively, and the averages are found to be $0.68,0.24$ and 0.28 respectively. ADR ranged between 29.40-57.50 nGy.h ${ }^{-1}$ with an average of 42.94 nGy.h $\mathrm{h}^{-1}$. AED ranged between $36.06-70.52 \mu \mathrm{Sv}^{-\mathrm{y}^{-1}}$, and the average is found to be $52.66 \mu \mathrm{Sv}^{-1} \mathrm{y}^{-1}$. While for non - oily samples (SN), Raeq ranged from 55.84 to $116.38 \mathrm{~Bq} \cdot \mathrm{kg}^{-1}$, with an average of $85.43 \mathrm{~Bq} . \mathrm{kg}$ ${ }^{-1}$. $\mathrm{I}_{\gamma}, \mathrm{H}_{\mathrm{ex}}$ and $\mathrm{H}_{\text {in }}$ ranged between 0.47-0.91, 0.15-0.33 and 0.17-0.38 respectively, and the averages are found to be $0.68,0.24$ and 0.28 respectively. ADR ranged between 29.40-57.50 nGy.h ${ }^{-1}$ with an average of 42.94 nGy.h ${ }^{-1}$. AED ranged between $36.06-70.52 \mu \mathrm{Sv}^{-1} \mathrm{y}^{-1}$, and the average is found to be $52.66 \mu \mathrm{Sv}^{-1}{ }^{-1}$. The obtained results were compared with the permissible global average values, and all radiation hazard indices were found to

be less than these. This confirmed that there are no current radiological hazards, neither on health nor the surrounding environment.
Despite this, the statistical K-S and M-W tests between the oily and non-oily samples showed that there are statistically some differences at the significance level $(\mathrm{p}<0.05)$ for the benefit of the oily samples, as shown in table 5 . The results also illustrated that the radiation hazard indices differ from one region to another, as the highest values of $\mathrm{Ra}_{\mathrm{eq}}, \mathrm{I} \gamma, \mathrm{H}_{\mathrm{ex}}, \mathrm{ADR}$, and AED for oily samples are at Almazarie (position 8), and the lowest values are at Almumlah (position 26). As for $\mathrm{H}_{\text {in }}$, the highest value is at Alrubue (position 14), and the lowest value is at Almumlah (position 26). Concerning the non- oily samples, the highest values of Raeq, $\mathrm{I}, \mathrm{H}_{\mathrm{ex}}$, ADR and AED are at Alhaway (position 24), and the lowest values are at Althania (position 22). As for Hin, the highest value is at Alhaway (position 24), and the lowest value is at Almumlah (position 35). To clarify the distribution of these indices in the study area. The pictorial map for Raeq. is shown in figure 2. Moreover, in each study area, the other indices, I_ $\gamma$, Hex, ADR, and AED showed the same behavior as the Raeq. Figure 3 shows the radiation hazard map of Hin.

Table 5. Descriptive statistics for all sand samples.

\begin{tabular}{|c|c|c|c|c|c|c|c|c|c|}
\hline \multirow{2}{*}{ indice } & \multirow{2}{*}{$\begin{array}{c}\text { Sample } \\
\text { Type }\end{array}$} & \multirow{2}{*}{ Variance } & \multirow{2}{*}{ Std. Dev. } & \multirow{2}{*}{ Skewness } & \multirow{2}{*}{ Kurtosis } & \multicolumn{2}{|c|}{ K. S. Test } & \multicolumn{2}{|c|}{ M. W. Test } \\
\hline & & & & & & $Z$ & Sig. & $Z$ & Sig. \\
\hline \multirow{2}{*}{$\mathrm{Ra}_{\mathrm{eq}}$} & so & 311.071 & 17.367 & $-0.401 \pm 0.501$ & $-1.127 \pm 0.972$ & \multirow{2}{*}{1.449} & \multirow{2}{*}{0.030} & \multirow{2}{*}{-2.088} & \multirow{2}{*}{0.037} \\
\hline & SN & 147.829 & 12.159 & $0.657 \pm 0.597$ & $0.191 \pm 1.154$ & & & & \\
\hline \multirow{2}{*}{ Ip } & so & 0.017 & 0.129 & $-0.354 \pm 0.501$ & $-1.135 \pm 0.972$ & \multirow{2}{*}{1.449} & \multirow{2}{*}{0.030} & \multirow{2}{*}{-2.088} & \multirow{2}{*}{0.037} \\
\hline & SN & 0.008 & 0.917 & $0.752 \pm 0.597$ & $0.3231 \pm 1.154$ & & & & \\
\hline \multirow{2}{*}{$\mathrm{H}_{\mathrm{ex}}$} & so & 0.003 & 0.050 & $-0.382 \pm 0.501$ & $-1.159 \pm 0.972$ & \multirow{2}{*}{1.449} & \multirow{2}{*}{0.030} & \multirow{2}{*}{-2.088} & \multirow{2}{*}{0.037} \\
\hline & SN & 0.001 & 0.346 & $0.677 \pm 0.597$ & $0.185 \pm 1.154$ & & & & \\
\hline \multirow{2}{*}{$\mathrm{H}_{\text {in }}$} & so & 0.004 & 0.061 & $-0.566 \pm 0.501$ & $-0.720 \pm 0.972$ & \multirow{2}{*}{1.587} & \multirow{2}{*}{0.013} & \multirow{2}{*}{-2.458} & \multirow{2}{*}{0.014} \\
\hline & SN & 0.001 & 0.383 & $0.081 \pm 0.597$ & $-0.065 \pm 1.154$ & & & & \\
\hline \multirow{2}{*}{ ADR } & so & 66.591 & 8.160 & $-0.394 \pm 0.501$ & $-1.097 \pm 0.972$ & \multirow{2}{*}{1.449} & \multirow{2}{*}{0.030} & \multirow{2}{*}{-2.054} & \multirow{2}{*}{0.040} \\
\hline & SN & 32.942 & 5.740 & $0.6941 \pm 0.597$ & $0.279 \pm 1.154$ & & & & \\
\hline \multirow{2}{*}{ AED } & so & 100.156 & 10.008 & $-0.394 \pm 0.501$ & $-1.097 \pm 0.972$ & \multirow{2}{*}{1.449} & \multirow{2}{*}{0.030} & \multirow{2}{*}{-2.054} & 000 \\
\hline & SN & 49.546 & 7.039 & $0.6941 \pm 0.597$ & $0.279 \pm 1.154$ & & & & 0.040 \\
\hline
\end{tabular}

\section{DISCUSSION}

In this study, radiation hazard indices $\mathrm{Ra}_{\mathrm{eq}}, \mathrm{I}_{\gamma}$, $\mathrm{H}_{\text {ex }}, \mathrm{H}_{\text {in }}, \mathrm{ADR}, \mathrm{AED}_{\text {indoor }}$ and $\mathrm{AED}_{\text {outdoor }}$ were determined for thirty five sand samples in Ma'rib - Yemen using Gamma-ray spectrometry system with HPGe detector. The results of these measurements showed that the averages of $\mathrm{Ra}_{\mathrm{eq}}$, 620
$\mathrm{I}_{\gamma}, \mathrm{H}_{\mathrm{ex}}, \mathrm{H}_{\mathrm{in}}$ ADR and AED for oily samples were 90.770 (Bq. $\mathrm{Kg}^{-1}$ ), 0.716, 0.251, 0.295, 45.440 (nGy.h ${ }^{-1}$ ), and 55.727( $\mu$ Sv. $\left.y^{-1}\right)$, respectively. As for non-oily samples, they were 90.770 (Bq. Kg-1 ${ }^{-1}, 0.716,0.251,0.295,45.440$ (nGy.h-1 ${ }^{-1}$, and $55.727\left(\mu \mathrm{Sv} . \mathrm{y}^{-1}\right)$, respectively.

These values compared with the world values reported by UNSCEAR 2000 (17) were lower. Int. J. Radiat. Res., Vol. 19 No. 3, July 2021 
However, K-S and M-W tests were performed on the raw data to distinguish the differences between the oily and non-oily samples, at significance level $(\mathrm{P}<0.05)$. K-S and $\mathrm{M}-\mathrm{W}$ tests indicate statistically significant differences in favour of sample from oily societies. The differences in the distribution of the $\mathrm{Ra}_{\mathrm{eq}}, \mathrm{I}_{\gamma}, \mathrm{H}_{\mathrm{ex}}$, $\mathrm{H}_{\text {in, }}$ ADR, and AED might have resulted from the contribution of the oil and gas industries and the geology of the study area.

The radiation hazard indices of sand samples were compared with results obtained by other researchers in different areas of oil and gas societies around the world, as shown in table 6. From table 6, the minimum value of $\mathrm{Ra}_{\mathrm{eq}}$ in this work is higher than the ones in Egypt, Turkey, and Kuwait, and less than the ones recorded in Saudi Arabia (25) and China (26). The maximum value is higher than the ones in Egypt, Turkey, Saudi Arabia, and Kuwait, and less than the value in China. The minimum and maximum values of $\mathrm{I}_{\gamma}$ are higher thanthe ones in Egypt and Kuwait. The minimum and maximum values of $\mathrm{H}_{\text {ex }}$ are higher than the values in Egypt, Turkey, and Kuwait, and less than the recorded ones in Saudi Arabia and China. The minimum and maximum values of $\mathrm{H}_{\text {in }}$ are higher than the ones in Egypt, Turkey, and Kuwait, and less than the recorded ones in Saudi Arabia. For the ADR, while the minimum level in the current study is higher than the level in Turkey (17), Egypt (18), Sudan (29) , and Kuwait (28) and is less than the level recorded in Saudi Arabia (25) China (26) and Sri Lanka (27). Finely, the minimum limit of AED is higher than the ones in Egypt (18), Turkey (17), Saudi Arabia (25), Kuwait (28)and Sudan (29).

Table 6. Comparison of radiation hazard indices of sand samples with different areas of oil and gas societies around the world.

\begin{tabular}{|c|c|c|c|c|c|c|c|c|}
\hline Country & Rang & $\mathrm{Ra}_{\mathrm{eq}} \mathrm{Bq} \cdot \mathrm{Kg}^{-1}$ & $I_{y}$ & $\mathrm{H}_{\mathrm{ex}}$ & $\mathrm{H}_{\text {in }}$ & ADR nGy.h ${ }^{-1}$ & AED $\left(\mu S v \cdot y^{-1}\right)$ & Ref. \\
\hline \multirow{2}{*}{ Yemen } & Min & 55.84 & 0.47 & 0.15 & 0.17 & 29.40 & 36.06 & \multirow{2}{*}{ (this study) } \\
\hline & Max & 116.38 & 0.91 & 0.33 & 0.38 & 57.50 & 70.52 & \\
\hline \multirow{2}{*}{ Egypt } & Min & 25.50 & 0.18 & 0.06 & 0.07 & 11.49 & 10 & \multirow[t]{2}{*}{ (18) } \\
\hline & Max & 73.40 & 0.59 & 0.21 & 0.26 & 37.71 & 50 & \\
\hline \multirow{2}{*}{ Turkey } & Min & 16.50 & - & 0.04 & 0.06 & 7.80 & 9.60 & \multirow[t]{2}{*}{ (17) } \\
\hline & Max & 106.80 & - & 0.29 & 0.35 & 51.70 & 56.20 & \\
\hline \multirow{2}{*}{ Saudi Arabia } & Min & 64.40 & - & 0.17 & 0.22 & 31.30 & 19 & \multirow{2}{*}{ (25) } \\
\hline & Max & 111.80 & - & 0.31 & 0.39 & 55.61 & 34 & \\
\hline \multirow{2}{*}{ China } & Min & 134.80 & - & 0.36 & - & 64.50 & 79 & \multirow[t]{2}{*}{ (26) } \\
\hline & Max & 151.40 & - & 0.41 & - & 74.60 & 91 & \\
\hline \multirow{2}{*}{ Sri Lanka } & Min & - & - & - & - & - & 42.07 & \multirow[t]{2}{*}{ (27) } \\
\hline & Max & - & - & - & - & - & 51.86 & \\
\hline \multirow{2}{*}{ Kuwait } & Min & 6.7 & 0.03 & 0.02 & 0.03 & 3.50 & 4.30 & \multirow[t]{2}{*}{ (28) } \\
\hline & Max & 75 & 0.27 & 0.20 & 0.35 & 35.60 & 43.60 & \\
\hline \multirow{2}{*}{ Sudan } & Min & - & - & - & - & 23.42 & 20 & \multirow[t]{2}{*}{ (29) } \\
\hline & Max & - & - & - & - & 75.46 & 90 & \\
\hline
\end{tabular}

and less than the ones in China and Sri Lanka (27). The maximum limit is higher than the values in Egypt, Turkey, Saudi Arabia, Sri Lanka, and Kuwait, and less than the ones recorded in Sudan and China.

In general, by examining the results in tables 3,4 and 5 and figures 2 and 3, findings revealed that the listed values are below the global mean levels of risks, indicating that the probability of radiation hazards is very low in the area under observation. However, variation is observed in the concentration of radiation in this area. A higher concentration of radioactivity was observed in the southeast of Ma'rib Governorate, where, waste petroleum is disposed off. It can be noted from the above-discussion that the highest values are in the southeastern sites that extends to the centre of the Governorate due to the presence of petroleum waste dumping areas as well as performing the oil and gas production processes in these regions. The higher concentration of radioactivity in these sites may 
be attributed to the leakage of radionuclides resulting from the oil and gas industry. Another justification can be attributed to the geological formation of this studied area. In general, currently there are no any significant radiological hazards to the population living in this area and the surrounding environment.

\section{CONCLUSION}

Based on the measured values of radioactivity concentrations in collected sand samples, most of the radiological parameters including radioactive hazard coefficients for radium equivalents, the efficacy concentration factor, the internal and external risk coefficient, the absorbed dose, and the effective dose were found to be within the permissible limit of the global values, and therefore, poses no radiation hazards for the inhabitants of this area.

\section{ACKNOWLEDGEMENT}

Authors acknowledge College of Nuclear Science and Technology of Harbin Engineering University, National Atomic Energy Commission of Yemen (NATEC), and Institute of Technical Physics, Heilongjiang Academy of Sciences. Further, the authors would like to thank Dr. Ihsan Ullah Khan from Pakistan for his helping and cooperation.

\section{Conflicts of interest: Declared none.}

\section{REFERENCES}

1. Oladele B, Arogunjo A, Aladeniyi K (2018) Indoor and outdoor gamma radiation exposure levels in selected residential buildings across Ondo state, Nigeria. Int J Radiat Res, 16(3): 363-70.

2. Hrichi H, Baccouche S, Belgaied J-E (2013) Evaluation of radiological impacts of tenorm in the Tunisian petroleum industry. J Environmental Radioactivity, 115: 107-13.

3. Ali MM, Zhao H, Li Z, Maglas NN (2019) Concentrations of TENORMs in the petroleum industry and their environ- mental and health effects. RSC Advances, 9(67): 39201-29.

4. Ali MMM, Zhao H, Li Z, Ayoub AAT (2020) A review about radioactivity in TENORMs of produced water waste from petroleum industry and its environmental and health effects. IOP Conference Series: Earth and Environ Sci, 467: 012120.

5. Khan I, Qin Z, Xie T, Bin Z, Li H, Sun W, et al. (2020) Evaluation of health hazards from radionuclides in soil and rocks of North Waziristan, Pakistan. Int J Radiat Res, 18(2): 24353.

6. Khan IU, Sun W, Lewis E (2020) Review of low-level background radioactivity studies conducted from 2000 to date in people Republic of China. J Radiat Res Appl Sci, 13 (1) :406-15.

7. Usikalu M, Rabiu A, Oyeyemi KD, Achuka J, Maaza M (2017) Radiation hazard in soil from Ajaokuta Northcentral Nigeria. Int J Radiat Res, 15(2): 219-24.

8. Isinkaye M, Jibiri N, Bamidele S, Najam L (2018) Evaluation of radiological hazards due to natural radioactivity in bituminous soils from tar-sand belt of southwest Nigeria using HpGe-Detector. Int J Radiat Res, 16(3): 351-62.

9. Khan IU, Sun W, Lewis E (2020) Radiological Impact on Public Health from Radioactive Content in Wheat Flour Available in Pakistani Markets. J Food Protection, 83 (2):377-82.

10. Arafin SAK, El-Taher A, Fazlul Hoque AKM, Ashraful Hoque $M$, Ferdous J, Joynal Abedi M (2020) Natural gamma radiation level detection in agriculture soil after Aila disaster and comparison with deep soil gamma activity in a specific area of Sundarban region, Satkhira, Banglsdesh. Int J Radiat Res, 18(3): 397-404.

11. Mouandza S, Moubissi A, Abiama P, Ekogo T, Ben-Bolie G (2018) Study of natural radioactivity to Assess of radiation hazards from soil samples collected from Mounana in south-east of Gabon. Int J Radiat Res, 16(4): 443-53.

12. Taqi A, Shaker A, Battawy A (2018) Natural radioactivity assessment in soil samples from Kirkuk city of Iraq using HPGe detector. Int J Radiat Res, 16(4): 455-63.

13. Gulan L, Milenkovic B, Stajic JM, Vuckovic B, Krstic D, Zeremski T, et al. (2013) Correlation between radioactivity levels and heavy metal content in the soils of the North Kosovska Mitrovica environment. Environmental Science: Processes \& Impacts, 15(9): 1735-42.

14. National Information Center Y-R (2019) Administrative division of Ma'rib governorate for local administration (Fourth Conference of Local Councils - 2006). 2006 [cited 2019 9/4/2019 ]. Available from: https://www.yemennic.info/gover/mareb/classoff/.

15. Our Yemen website management (2019) Comprehensive guide, your comprehensive guide to Yemen "all regions" 2015 [cited 2019 10/1/2019]. Available from: http:// www.yemenna.com

16. Khandaker MU, Asaduzzaman K, Sulaiman AFB, Bradley DA, Isinkaye MO (2018) Elevated concentrations of naturally occurring radionuclides in heavy mineral-rich beach sands of Langkawi Island, Malaysia. Marine Pollution Bulletin, 127: 654-63.

17. Özmen S, Cesur A, Boztosun I, Yavuz M (2014) Distribution Int. J. Radiat. Res., Vol. 19 No. 3, July 2021 
of natural and anthropogenic radionuclides in beach sand samples from Mediterranean Coast of Turkey. Radiation Physics and Chemistry, 103: 37-44.

18. Fares S (2017) Measurements of natural radioactivity level in black sand and sediment samples of the Temsah Lake beach in Suez Canal region in Egypt. J Radiat Res Appl Sci, 10(3): 194-203.

19. UNSCEAR (2000) Sources and Effects of Ionizing Radiation. New York.

20. Alaboodi AS, Kadhim NA, Abojassim AA, Baqir Hassan A (2020) Radiological hazards due to natural radioactivity and radon concentrations in water samples at Al-Hurrah city, Iraq. Int J Radia Res, 18(1):1-11.

21. Elsaman R, Ali GAM, Uosif MAM, El-Taher A, Chong KF (2020) Transfer factor of natural radionuclides from clay loam soil to sesame and Cowpea: radiological hazards. Int J Radiat Res,18(1): 157-66.

22. Adewoyin OO, Omeje M, Joel ES, Odetunmibi OA (2019) Comparative assessment of natural radioactivity and radiological hazards in building tiles and sharp sand sourced locally and those imported from China and India. Int J Radiat Res, 17(3): 463-71.

23. Faweya EB, Olowomofe GO, Akande HT, Faweya O, Adesakin GE (2019) Evaluation of radon exhalation rate and excessive lifetime cancer risk in Dumpsites in Ondo city Southwestern Nigeria. Int J Radiat Res, 17(3): 379-90.

24. Al-Kaabi MA and Hmood AN (2019) Study of the Radiological Doses in Karbala city. Int J Radiat Res, 17(1): 171-6.

25. Alaamer AS (2012) Measurement of natural radioactivity in sand samples collected from Ad Dahna desert in Saudi Arabia. World Journal of Nuclear Science and Technology, 2: 187-91.

26. Xinwei $L$ and Xiaolan $Z$ (2006) Measurement of natural radioactivity in sand samples collected from the Baoji Weihe Sands Park, China. Environmental Geology, 50(7): 977-82.

27. Ratnayake R, Gamage SS, Senadhira A, Weerasinghe D, Waduge $V$ (2017) NORM analysis of the reservoir sand section in the Dorado natural gas discovery, Mannar basin offshore Sri Lanka. Journal of the Geological Society of India, 89(6): 683-8.

28. Hassan NM, Mansou N, Salama S, Seoud M (2019) Assessment of radiological hazards of using petroleum raw materials and their waste. Radiation Protection Dosimetry, 185 (4): 494-506.

29. Abu-baker AOK, Elhassan A, Osman AH, Elfaki AAA, Elobaid RA (2016) Measurement of activity concentration, absorbed dose rate and annual effective dose of natural occurring radioactive material (NORM) in samples encountered during oil \& gas industry. IOSR J Appl Phys, 8: 89-95. 
